\title{
Evaluasi Orientasi Layanan Sebagai Bagian dari Budaya Organisasi dan Efeknya Terhadap Kinerja Organisasi
}

\author{
Ahyar Yuniawan \\ Fakultas Ekonomi, Universitas Diponegoro \\ E-mail: ahyar_yuniawan@yahoo.com
}

\begin{abstract}
The study aims to evaluate the university service orientation as social variable, to empirically test its relationship to organizational performance measures and to provide managerial implications. The premise behind the study is that service-oriented organizations choosing to emphasize service excellence as a valueadded deliverable will perform significantly better than organizations that do not possess this orientation. The study employes a survey method and uses a proportional random sampling as sampling technique. The results of the study confirm that service orientation increases business performance and employee service outcomes; employee service outcomes increases business performance, and the total effects of service orientation increases employee service outcomes.
\end{abstract}

Keywords: Service orientation, organizational culture, employee service outcomes, and business performance.

\section{PENDAHULUAN}

Kinerja organisasi adalah kompleks dan merupakan fungsi dari banyak variabel. Sebuah variabel multifacet yang terus mendapat perhatian dari akademisi dan profesional bisnis adalah orientasi organisasi. Meskipun sulit untuk dikonseptualisasi dan diukur, orientasi organisasi secara langsung mempengaruhi kinerja organisasi. Orientasi organisasi, khususnya orientasi layanan, telah terbukti memiliki pengaruh signifikan pada kinerja organisasi (Homburg et al., 2002.; Kohli \& Jaworski, 1990; Narver \& Slater, 1990; Lytle et al., 1998; Lytle et al., 2000). Orientasi layanan dikonseptualisasikan sebagai predisposisi organisasi, preferensi atau afinitas organisasional strategik untuk layanan prima.

Rencana organisasi berbasis layanan, keterlibatan proaktif dan menghargai praktek-praktek penyampaian layanan, proses dan prosedur yang merefleksikan keyakinan bahwa keprimaan layanan adalah suatu prioritas strategik dan bahwa layanan berdampak signifikan dalam penciptaan nilai superior, kepuasan pelanggan, keunggulan kompetitif, pertumbuhan dan profitabilitas. Orientasi layanan dapat dipandang sebagai respon strategis terhadap untuk intelijensi pasar-cara tertentu dalam implementasi konsep pemasaran, bersaing dengan penggunaan layanan prima untuk meningkatkan nilai pelanggan dan keunggulan kompetitif.

Dalam studi ini, orientasi layanan organisasional didefinisikan sebagai suatu serangkaian kebijakan, praktek, dan prosedur organisasi yang ditujukan untuk mendukung dan menghargai perilaku penyampaian layanan yang menciptakan dan memberikan layanan prima (Lytle et al., 1998). Terdapat perhatian yang meningkat dalam riset orientasi layanan karena hal ini menjadi faktor penentu dalam penciptaan layanan pelanggan superior dan nilai pelanggan. Keluarankeluaran organisasional seperti profit, pertumbuhan, kepuasan pelanggan, kepuasan dan loyalitas karyawan diakui sebagai keluaran orientasi layanan organisasional (Albrecht \& Zemke, 1985; Heskett et al., 1997; Henkoff, 1994; Johnson, 1996; O'Connor \& Shewchuk, 1995; Rust et al., 1996; Sasser \& Jones, 1995; Schneider \& Bowen, 1995).

Sebagai gambaran untuk mencapai prestasi internasional, perguruan tinggi perlu secara aktif mempersiapkan data dan menginformasikan data tersebut ke lembaga pemeringkat universitas tingkat internasional. Hal tersebut menjadi sangat penting sehingga lembaga-lembaga tersebut dapat mengetahui keberadaan universitas tertentu. Data-data akurat yang perlu disiapkan. Misalnya, data jumlah mahasiswa domestik dan asing yang belajar di perguruan tinggi tertentu yang ada di Indonesia karena hal tersebut menunjukkan gambaran tentang daya tarik perguruan tinggi tertentu di masyarakat internasional. Di Undip, jumlah mahasiswa asing yang belajar ada yang berasal dari negara-negara di Asia tenggara, Korea, Jepang dan Afrika, dan bahkan, dari Amerika Serikat. Hal lain yang tidak kalah penting untuk diinformasikan adalah kegiatan riset dan pendanaannya (nasional/internasional) karena menunjukkan seberapa besar minat perguruan tinggi untuk menghasil- 
kan temuan-temuan penelitan yang memiliki manfaat yang tinggi bagi masyarakat. Juga, inisiatif untuk terus mengembangkan diri menjadi perguruan tinggi yang berkualitas. Informasi lain yang berkaitan dengan sarana penunjang kehidupan akademik juga menjadi bahan penilaian yang cukup penting di mana dana yang disiapkan memang untuk kepentingan pengembangan pepustakaan dan akses terhadap jurnal internasional.

Lembaga pemeringkatan universitas juga mempunyai konsentrasi dan penilaian yang sangat tinggi tentang kualitas lulusan Undip. Indikator yang digunakan adalah jumlah masa tunggu sampai lulusan mendapatkan pekerjaan yang sesuai dengan latar belakang pendidikan. Semakin singkat masa tunggu semakin baik kualitas lulusan dari perguruan tinggi tersebut karena memiliki daya tarik yang tinggi di pasar tenaga kerja. Selain lulusan, iklim belajar di perguruan tinggi ketika mahasiswa menempuh studi juga mempengaruhi penilaian, misalnya dalam hal rasio mahasiswa dan dosen untuk setiap kelas karena akan mampu menggambarkan tentang potensi efektifitas pembelajaran dalam kelas. Dosen yang mengajar dengan jumlah mahasiswa yang banyak bahkan melebihi standar rasio yang baik, akan membuat materi perkuliahan tidak begitu mudah dipahami dan diterima oleh mahasiswa.

Aspek lainnya adalah jumlah artikel yang dipublikasikan di jurnal-jurnal internasional memiliki nilai yang sangat signifikan dan memengaruhi peringkat perguruan tinggi tertentu. Banyaknya publikasi internasional akan mempermudah penilai untuk mencari dan menemukan tentang perguruan tinggi yang akan dinilai. Pihak universitas harus secara aktif mendorong dan menstimulasi staf akademiknya untuk aktif menulis dan mengirimkan artikel ilmiah ke jurnal-jurnal internasional. Pemanfaatan teknologi informasi menjadi sebuah keharusan untuk internasionalisasi perguruan tinggi. Website menjadi sarana komunikasi yang ampuh untuk menginformasikan keberadaan perguruan tinggi ke pihak luar. Saat ini, Undip terus menerus memberikan perhatian yang serius pada penataan website dari tampilan sampai ke isi website. Penilaian dari lembaga pemeringkat pada website tidak harus menggunakan Bahasa Inggris, karena meskipun menggunakan Bahasa Indonesia yang dikemas dan disajikan dengan menarik akan mampu menaikkan ranking. Informasi yang berkaitan dengan mahasiswa asing yang belajar di perguruan tinggi sebaiknya ditonjolkan lebih serius dan dimunculkan lebih sering sehingga meyakinkan penilaian itu sendiri.

Dalam rangka peningkatan kapasitas Undip menuju World Class University, pada tahun 2009 telah diupayakan adanya penambahan jurnal elek- tronik dari berbagai sumber yaitu SpringerLink, ScienceDirect (Elsevier). Jurnal-jurnal tersebut untuk melengkapi e-jurnal yang telah ada sebelumnya yaitu Proquest. Seluruh jurnal yang ada dapat diakses langsug (fulltext) melalui jaringan internet di lingkungan Undip. Selain itu, terdapat beberapa indikator konkrit yang dipergunakan untuk kepentingan penilaian pemeringkatan, misalnya yang digunakan oleh Quality Standardization (QS). Indikator yang digunakan adalah melihat kualitas hasil penelitian (dalam hal aktualitas, nilai manfaat hasil penelitian), kualitas lulusan (dalam hal kemampuan atau kemudahan mendapatkan pekerjaan), pengamatan internasional berupa penilaian dari lembaga internasional lainnya serta kualitas internal proses belajar mengajar. Meskipun telah masuk dalam jajaran world class university dimana sudah banyak fakultas-fakultas yang ada di Undip masuk dalam peringkat 400 dunia, Undip tetap akan terus menerus mengejar dan menaikkan peringkat, karena pada periode yang lain mengalami penuruan peringkat dan keluar dari peringkat 500 dunia.

Gambaran tersebut memberikan petunjuk bahwa perubahan orientasi organisasional (dalam hal ini orientasi layanan) dapat memengaruhi kinerja organisasi. Hanya saja, hingga saat ini masih sedikit riset empiris yang berfokus ada pemahaman hubungan kompleks antara orientasi pelayanan dan kinerja organisasi. Bahkan, riset-riset yang ada cenderung mengukur dan menguji konstruk orientasi layanan tanpa memperhatikan secara serius konseptualisasi dan pengukurannya sebagai suatu elemen budaya organisasi. Orientasi organisasional pada dasarnya dikonstruksi secara sosial karena tumbuh sebagai hasil interaksi antara organisasi dan anggotanya). Tetapi, kebanyakan peneliti menilai dan mengukur orientasi layanan dengan menggunakan informan tunggal pada level manajemen (Homburg et al., 2002; Kohli \& Jaworski, 1990; Narver \& Slater, 1990). Pendekatan ini membatasi dan menghalangi pemahaman yang lebih tepat mengenai suatu variabel organisasional yang kompleks.

Studi ini masih melihat perlunya riset lebih jauh untuk menilai/mengevaluasi dan menguji hubungan antara orientasi layanan dan kinerja organisai agar dapat memberikan manfaat teoritis dan manajerial. $\mathrm{Di}$ samping itu, hingga saat ini masih sedikit riset empiris yang berfokus ada pemahaman hubungan kompleks antara orientasi pelayanan dan kinerja organisasi. Secara spesifik, studi ini bertujuan untuk mengukur hubungan antara orientasi layanan dan level keluaran karyawan, mengukur hubungan antara orientasi layanan dan bisnis/organisasi, serta mengukur hubungan antara keluaran layanan karyawan dan bisnis/organisasi. 


\section{KAJIAN TEORITIS}

\section{Variabel-Variabel Penelitian}

Model umum dipertimbangkan dalam penelitian ini dibentuk berdasarkan perspektif manajemen kontingensi yang menganggap organisasi sebagai elemen dari sistem terbuka dimana organisasi melakukan interaksi terus-menerus dengan lingkungannya (Aldrich, 1979; Katz \& Kahn, 1966; Keats \& Hitt, 1988; Pfeffer \& Salancik, 1978). Bahkan diasumsikan bahwa hasil-hasil kinerja, dan terutama, keunggulan kompetitif, organisasi mampu membantunya untuk menyesuaikan diri dengan perubahan lingkungannya-mangelola hubungan kritis antara variabel internal dan eksternal yang memperkuat penciptaan berkelanjutan bagi nilai-nilai pelanggan yang superior (Day, 1990; Jaworski \& Kohli, 1993; Narva \& Slater, 1990).

Orientasi layanan adalah independent variabel. Studi ini mempertimbangkan variabel orientasi layanan sebagai suatu elemen iklim organisasi. Dengan demikian, variabel ini diuji sebagai hasil persepsi atas penataan kebijakan-kebijakan, praktek-praktek dan prosedur-prosedur atau karakteristik desain internal (Homburg et al., 2002). Orientasi layanan diukur dengan instrument yang dikembangkan oleh Lytle et al. (1998). Skala pengukurannya terdiri dari 10 dimensi, yakni: (1) kepemimpinan pelayan, (2) visi layanan, (3) perlakuan terhadap pelanggan, (4) pemberdayaan karyawan, (5) pelatihan layanan, (6) penghargaan layanan, (7) pencegahan kegagalan layanan, (8) recovery kegagalan layanan atau service failure recovery, (9) teknologi layanan, dan (10) komunikasi standar layanan.

Keluaran organisasi secara luas dimodelkan dalam hal jumlah hubungan antara variabel organisasi dan pasar spesifik (Bourgeois, 1980; Chakravarthy, 1982; Conant et al., 1990; Deshpande \& Webster, 1989; Hofstede et al., 1990; Pettigrew, 1979; Schein, 1985; Smircich, 1983). Keluaran organisasi didefinsikan dalam hal kinerja bisnis (operasional/financial) dan keluaran karyawan (Venkatraman \& Ramanujam, 1986).

Keluaran karyawan. Para peneliti menyakini bahwa organisasi layanan yang berorientasi pelanggan akan memperoleh manfaat sosial dan psikologis yang baik (Kohli \& Jaworski, 1990; Jaworski \& Kohli, 1993; Kelley, 1992; Schlesinger \& Heskett, 1991). Pengujian atas manfaat-manfaat ini akan menunjukkan seberapa efektif organisasi menunjukkan kinerjanya dalam hal sikap-sikap karyawan yang menjadi bahan dasar yang digunkanan untuk menciptakan dan menyampaian layanan pelanggan yang superior.

\section{Hipotesis}

Ruang lingkup penelitian dan model umum yang membawa kita untuk mengajukan dua asumsi dasar berikut mengenai orientasi pelayanan dan kinerja. Ruang lingkup dan kedalaman studi ini memberikan kesempatan unik untuk menyelidiki kompleksitas satu pertanyaan dasar: apakah orientasi pelayanan sebuah organisasi mempengaruhi bottom line organisasi? Jika demikian, nilai tambah harus memberikan keunggulan kompetitif bagi perusahaan yang memilih untuk bersaing berdasarkan keunggulan layanan. Karena itu, para peneliti menyakini bahwa organisasi yang berorientasi layanan akan lebih mungkin untuk mendapatkan keuntungan kompetitif dengan menciptakan dan memberikan nilai pelanggan yang superior. Selain itu, sikap karyawan mempengaruhi persepsi pelanggan tentang kualitas layanan. Hal ini terjadi terutama karena sikap karyawan mempengaruhi nilai karyawan yang pada akhirnya mempengaruhi nilai pelanggan (Chase \&Bowen, 1991; Kohli \& Jaworski, 1990). Dengan demikian, pengalaman karyawan mereka sendiri dengan lingkungan layanan internal mempengaruhi pengalaman layanan pelanggan secara keseluruhan (Bowen et al., 1989). Hubungan ini ada untuk suatu alasan karena nilai persepsi pelanggan, yang menuntun pada kinerja organisasi, sangat bergantung sikap tentang kesaksian mereka terhadap penyedia layanan (Crosby, 1991).

Penelitian yang dilaporkan oleh Jaworski \& Kohli (1993) menunjukkan bahwa orientasi pelanggan mengarah ke rasa kebanggaan terikat kepada sebuah organisasi, dimana semua departemen dan individu bekerja menuju tujuan bersama untuk melayani pelanggan. Pencapaian hasil ini menghasilkan perasaan dalam karyawan untuk berbagi rasa tentang pemberian kontribusi yang berharga, sebagaimana perasaan tingkat kepuasan kerja dan komitmen yang lebih tinggi terhadap organisasi (Kohli \& Jaworski, 1990). Selain itu, organisasi yang fokus pelanggan memiliki karyawan yang sangat meyakini tujuan dan nilai-nilai organisasi serta bersedia untuk memberikan upaya yang besar atas nama organisasi dalam pencapaian tujuan-tujuan tersebut untuk mempertahankan keanggotaan organisasi (Deal \& Kennedy, 1982; Kelley, 1992; Schein, 1985). Schneider et al. (1992) melaporkan bahwa keluaran psikologis karyawan secara keseluruhan, seperti kepuasan kerja, secara signifikan yang berkaitan dengan gairah organisasi untuk memberikan pelayanan prima. Dengan demikian, para peneliti meyakini bahwa orientasi layanan organisasional akan berhubungan positif dengan keluaran psikologis karyawan. Literatur ini mendukung keyakinan bahwa 
hal ini pada gilirannya akan secara positif terkait dengan kinerja karyawan, kepuasan pelanggan, persepsi nilai pelanggan, dan kinerja bisnis pada akhirnya. Berdasarkan diskusi dan argumentasi yang ada, peneliti mengajukan beberapa hipotesis sebagai berikut:

H1: Semakin tinggi orientasi layanan, semakin tinggi tingkat keluaran layanan karyawan.

H2: Semakin baik tingkat keluaran layanan karyawan, semakin baik kinerja bisnis

H3: Semakin baik orientasi pelayanan, semakin baik kinerja bisnis.

\section{METODE PENELITIAN}

\section{Desain Penelitian}

Penelitian ini menggunakan desain deskriptif, data cross-sectional dan pendekatan survei. Pendekatan penelitian ini memungkinkan untuk karakterisasi kompleksitas isu-isu orientasi layanan tanpa mengabaikan isu generalisasi hasil-hasilnya. Penelitian organisasional banyak dilakukan dalam perspektif medium-grained untuk menjawab dua pertanyaan secara mendalam (praktek di seluruh organisasi) dan generalisasi dengan memasukkan organisasi dalam jumlah industri berbeda namun terbatas (Hofstede et al., 1990; Reynolds, 1986).

\section{Sampel}

Populasi dalam studi ini adalah seluruh anggota pimpinan dan karyawan di lingkungan fakultasfakultas di Undip, yaitu sebanyak 12 fakultas. Target sampelnya dalah seluruh dosen dan karyawan yang telah bekerja selama minimal 3 tahun. Metodologi ini digunakan karena tujuan dari penelitian ini adalah untuk lebih memahami isu-isu budaya yang terletak di level yang lebih dalam organisasi daripada belajar dengan menggunakan indikator tunggal tradisional. Pendekatan penentuan sampelnya adalah proporsional random sampling, dengan mempertimbangkan komposisi jumlah dosen dan karyawan di setiap fakultas.

Dengan mengacu ke aturan data sampel dalam pendekatan SEM, maka dibutuhkan data sebanyak $45 \times 5=225$ (Ferdinand, 2006). Selain itu, metode maximum likelihood estimation (MLE) memerlukan ukuran sampel antara 100-200 untuk dapat memberikan hasil yang valid dalam estimasi dan interpretasi hasil-hasil SEM. Apalagi 200 data dianggap sebagai ukuran sampel yang kritis (Hair et al., 1998). Adapun proporsi dosen dan karyawan yang terdapat di Universitas Diponegoro dapat dilihat dalam Tabel 1.
Tabel 1. Proporsi Data Dosen dan Karyawan untuk Penentuan Sampel

\begin{tabular}{|c|c|c|c|c|c|c|}
\hline Fakultas & Dosen & $\begin{array}{l}\text { Tenaga } \\
\text { Kepen- } \\
\text { didikan }\end{array}$ & Jumlah & $\begin{array}{l}\text { Pro- } \\
\text { porsi }\end{array}$ & $\begin{array}{c}\text { Respon- } \\
\text { den dosen }\end{array}$ & $\begin{array}{c}\text { Responden } \\
\text { Tenaga } \\
\text { Kependi- } \\
\text { dikan } \\
\end{array}$ \\
\hline$\overline{\mathrm{FK}}$ & 242 & 130 & 372 & 0.2 & 22 & 12 \\
\hline $\mathrm{FH}$ & 122 & 53 & 175 & 0.1 & 11 & 5 \\
\hline $\mathrm{FE}$ & 126 & 91 & 217 & 0.1 & 12 & 8 \\
\hline FT & 416 & 155 & 571 & 0.2 & 38 & 14 \\
\hline FPIK & 161 & 32 & 193 & 0.1 & 15 & 3 \\
\hline FKM & 64 & 39 & 103 & 0.0 & 6 & 4 \\
\hline FMIPA & 186 & 52 & 238 & 0.1 & 17 & 5 \\
\hline FISIP & 104 & 44 & 148 & 0.1 & 10 & 4 \\
\hline FIB & 102 & 48 & 150 & 0.1 & 9 & 4 \\
\hline F Psi & 63 & 20 & 83 & 0.0 & 6 & 2 \\
\hline \multirow{2}{*}{ F Pternak } & 127 & 57 & 184 & 0.1 & 12 & 5 \\
\hline & 1713 & 721 & 2434 & & 158 & 67 \\
\hline
\end{tabular}

Sumber: Kepegawaian UNDIP

\section{Pengumpulan Data}

Data-data empiris dikumpulkan dengan cara menyebarkan kuesioner secara langsung kepada para responden potensial dan bila tidak memungkinkan untuk segera diterima, peneliti akan menggunakan jasa pos berbayar (a reply-paid envelope) atau menyertakan perangko secukupnya untuk pengembalian. Para responden potensial diminta untuk mengindikasikan tingkat kesetujuannya pada skala Likert 7 poin yang terdapat dalam kuesioner. Proses pengiriman kepada responden potensial hingga kembali kepada peneliti di perkirakan memakan waktu 4 minggu, dengan perkiraan pengiriman sekitar 1 minggu, pengisian kuesioner 2 minggu, dan pengembalian 1 minggu. Terkait dengan uji nonrespon bias, dengan mengikuti Lambert \& Harrington (1990), maka data-data yang diperoleh akan dipisahkan berdasarkan waktu pengembaliannya hingga empat tahapan pengembalian. Bila diperlukan, dengan mengikuti model desain total dari Dilman (1978), surat follow-up berupa kartu pos yang akan dikirimkan dua minggu setelah survei tersebut dijalankan untuk mengingatkan partisipan agar mengembalikan kuesioner.

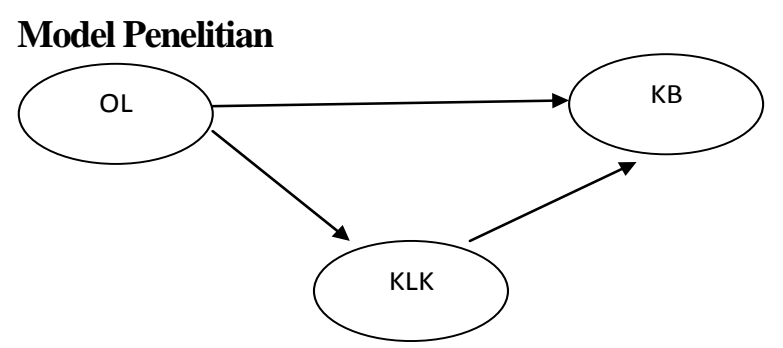

Sumber: Dikembangkan untuk studi ini, berdasarkan Lytle \& Timmerman (2006).

\section{Gambar 1. Model Penelitian}

Keterangan:

OL : Orientasi Layanan

KLK : Keluaran Layanan Karyawan

KB : Kinerja Bisnis 


\section{HASIL DAN PEMBAHASAN}

\section{Profil Responden}

Dari Tabel 2, ditunjukkan bahwa konsentrasi tinggi responden dosen dengan usia kisaran 25-35 tahun berada di Fakultas MIPA (100\%), usia 35-45 tahun berada di Fakultas Ilmu Budaya (100\%), usia 45-55 tahun berada di Fakultas MIPA (100\%) dan usia $>55$ tahun, masing-masing $100 \%$, berada di Fakultas Hukum, MIPA, Ilmu Budaya dan Peternakan. Sedangkan untuk karyawan, konsentrasi tinggi dengan usia kisaran 25-35 tahun berada di Fakultas Hukum (80\%), usia 35-45 tahun berada di Fakultas Hukum (100\%), usia 45-55 tahun berada di Fakultas Teknik (83\%) dan usia $>55$ tahun berada di Fakultas Ekonomi (100\%). Berdasarkan Tabel 3, tampak bahwa konsentrasi tinggi responden dengan jenis kelamin laki-laki yang bersedia berpartisipasi berada di Fakultas Hukum (70\%), Fakultas Teknik (78\%), Fakultas Perikanan dan Ilmu Kelautan (86\%), dan Fakultas MIPA (100\%). Sedangkan, konsentrasi tinggi responden dengan jenis kelamin perempuan berada di Fakultas Hukum (71\%), Fakultas MIPA (100\%), Fakultas Ilmu Budaya (83\%), Fakultas Psikologi (100\%), dan Fakultas Peternakan (100\%).

Di sisi lain, dalam kategori jabatan karyawan secara umum terlihat bahwa cukup banyak karyawan yang berpartisipasi dalam memberikan penilaian atas variabel-variabel yang menjadi perhatian dalam studi. Sedangkan, untuk dosen menunjukkan bahwa tingkat respon terbanyak didominasi oleh dosen dengan jabatan asisten ahli dan lektor. Jumlah yang cukup besar ini member indikasi bahwa tingkat kesediaan responden untuk berpartisipasi sudah baik dan memberikan tanda tentang makin baiknya persepsi kontribusi responden atas suatu riset.

Rekaman data responden berdasarkan masa kerja menunjukkan bahwa sebagian besar responden telah memiliki masa kerja antara 5-25 tahun. Hal ini memberikan indikasi bahwa persepsi mereka akan cenderung lebih baik/jujur atas variabel-variabel yang menjadi perhatian dalam studi. Pengalaman kerja yang cukup/baik akan membantu seorang responden untuk memahami dunia kerjanya secara lebih baik dan paham akan relevansinya dengan ukuran-ukuran lain yang berdampak pada perkembangan dan kinerja suatu organisasi.

\section{Hasil Uji Nonresponse Bias}

Dari 139 kuesioner yang dapat diolah, seluruh kuesioner diterima dalam 1 bulan pertama sehingga uji nonresponse bias tidak perlu dilakukan, karena semua responden dianggap telah memberikan respon yang tidak berbeda (Lambert \& Harrington, 1990; Hair et al., 1998).

Tabel 2. Profil Responden

\begin{tabular}{|c|c|c|c|c|c|c|c|c|c|c|}
\hline & & \multicolumn{9}{|c|}{ Fakultas* (dalam \%) } \\
\hline & & $\mathbf{K}$ & $\mathbf{H}$ & $\mathbf{E}$ & $\mathbf{T}$ & PIK & MIPA & IB & P1 & $\mathbf{P 2}$ \\
\hline KarakteristikResponden & Kategori & $\mathbf{D} / \mathbf{K}^{* *}$ & $\mathbf{D} / \mathbf{K}$ & $\mathbf{D} / \mathbf{K}$ & $\mathbf{D} / \mathbf{K}$ & $\mathbf{D} / \mathbf{K}$ & $\mathbf{D} / \mathrm{K}$ & $\mathbf{D} / \mathbf{K}$ & $\mathbf{D} / \mathbf{K}$ & $\mathbf{D} / \mathbf{K}$ \\
\hline \multirow[t]{4}{*}{ Usia } & $25-35$ th & $50 / 50$ & $20 / 80$ & $40 / 60$ & $33 / 67$ & $50 / 50$ & $100 / 0$ & $50 / 50$ & $75 / 25$ & $67 / 33$ \\
\hline & $35-45$ th & $60 / 40$ & $0 / 100$ & $43 / 57$ & $50 / 50$ & $57 / 43$ & $60 / 40$ & $100 / 0$ & $83 / 17$ & $20 / 80$ \\
\hline & $45-55$ th & $33 / 67$ & $50 / 50$ & $67 / 33$ & $17 / 83$ & $60 / 40$ & $100 / 0$ & $36 / 64$ & $67 / 33$ & $40 / 60$ \\
\hline & $>55$ th & & $100 / 0$ & $0 / 100$ & & & $100 / 0$ & $100 / 0$ & & $100 / 0$ \\
\hline \multirow[t]{2}{*}{ Kelamin } & $\mathrm{L}$ & $50 / 50$ & $30 / 70$ & $50 / 50$ & $22 / 78$ & $86 / 14$ & $100 / 0$ & $60 / 40$ & $62 / 38$ & $56 / 44$ \\
\hline & $\mathrm{P}$ & $50 / 50$ & 29/71 & $40 / 60$ & $50 / 50$ & $42 / 58$ & $100 / 0$ & $17 / 83$ & $100 / 0$ & $0 / 100$ \\
\hline \multirow[t]{5}{*}{ Pendidikan } & SMA & & $0 / 100$ & & $0 / 100$ & $0 / 100$ & & $0 / 100$ & & $0 / 100$ \\
\hline & Diploma & & & $0 / 100$ & $0 / 100$ & & & & $0 / 100$ & $0 / 100$ \\
\hline & Sarjana & $0 / 100$ & $0 / 100$ & $0 / 100$ & $0 / 100$ & $0 / 100$ & $50 / 50$ & $20 / 80$ & $75 / 25$ & $20 / 80$ \\
\hline & Master & $100 / 0$ & $100 / 0$ & $100 / 0$ & $100 / 0$ & $100 / 0$ & $100 / 0$ & $75 / 25$ & $100 / 0$ & $83 / 17$ \\
\hline & Doktor & & & $100 / 0$ & & $100 / 0$ & & & & $100 / 0$ \\
\hline \multirow[t]{5}{*}{ Jabatan**** } & A & 57 & 71 & & 73 & 37 & & 56 & 18 & 62 \\
\hline & AA & 29 & & 33 & 18 & 10 & 33 & 12 & 36 & 9 \\
\hline & $\mathrm{L}$ & 14 & 6 & 56 & 9 & 37 & 33 & 19 & 37 & 10 \\
\hline & LK & & 23 & 11 & & 16 & 34 & 13 & 9 & 19 \\
\hline & GB & & & & & & & & & \\
\hline \multirow[t]{6}{*}{ Masakerja } & $<5$ th & 25 & 6 & & 18 & & 9 & 13 & 50 & \\
\hline & $5-10$ th & 37 & 18 & 23 & & 5 & 18 & 6 & 17 & 20 \\
\hline & $10-15$ th & 25 & 6 & 23 & 9 & 11 & 46 & 6 & 25 & 25 \\
\hline & $15-20$ th & & 29 & 15 & 37 & 32 & & 19 & & 25 \\
\hline & $20-25$ th & & 35 & 31 & 27 & 47 & 18 & 50 & 8 & 10 \\
\hline & $>25$ th & 13 & 6 & 8 & 9 & 5 & 9 & 6 & & 20 \\
\hline
\end{tabular}

Sumber: data diolah

Keterangan:

* : K (kedokteran); H (hukum); E (ekonomi); T (teknik); PIK (perikanandanilmukelautan); MIPA (matematikandan IPA); IB (ilmubudaya); P1 (psikologi); dan P2 (peternakan)

** : D (dosen)/K (karyawan)

***: Berdasarkanpendidikandi manaA (admin), AA (asistenahli), L (lektor), LK (lektorkepala), GB (guru besar) 


\section{Hasil Analisis Common Method Bias}

Penelitian ini telah mengumpulkan data dari responden dosen dan karyawan yang berasal dari berbagai fakultas di UNDIP Semarang dengan mempertimbangkan kriteria yang telah ditetapkan sebelumnya. Berdasarkan data yang telah diperoleh, semua responden telah bekerja $\geq 3$ tahun. Keseluruhan data tersebut sudah cukup membuktikan bahwa upaya meminimalkan common method bias dapat dikatakan berhasil.

\section{Hasil Uji Reliabilitas dan Validitas}

Total nilai Cronbach's Alpha yang berada pada rentang 0.66 hingga 0.93 dianggap sangat baik dan dapat diterima (Hair et al., 1998; Sekaran, 2000). Unidimensionalitas butir-butir yang merupakan syarat perlu untuk analisis reliabilitas dan validasi konstruk menunjukkan bahwa untuk konstruk kinerja bisnis menunjukkan nilai GFI > 0.9 (Anderson \& Gerbing, 1991, dalam Ferdinand 2002). Sedangkan, untuk variabel orientasi layanan dan keluaran layanan karyawan masing-masing sebesar sebesar 0.63 dan 0.84. Namun, hasil-hasil ini sedikit dibawah dan/atau diatas nilai GFI Efektivitas Organisasi $-2^{\text {nd }}$ order variable - yaitu 0.727 (Yuniawan, 2009). Hasil-hasil ini diperoleh butir-butir tersebut tetap dipertahankan karena semua loading factornya $\geq 0.40$.

\section{Hasil Uji Reliabilitas Konstruk dan Variance- Extracted}

Tabel 3. Construct Reliability dan Variance-Extracted Setiap Konstruk

\begin{tabular}{|c|c|c|}
\hline Konstruk & Construct Reliability $(\alpha)$ & Variance-Extracted $*$ \\
\hline \multicolumn{3}{|c|}{ Orientasi Layanan: } \\
\hline VL & 0.797 & 0.672 \\
\hline KL & 0.870 & 0.692 \\
\hline PP & 0.715 & 0.459 \\
\hline PK & 0.648 & 0.389 \\
\hline GL & 0.834 & 0.715 \\
\hline PL & 0.748 & 0.599 \\
\hline TL & 0.838 & 0.723 \\
\hline PKL & 0.733 & 0.579 \\
\hline RKL & 0.883 & 0.791 \\
\hline KSL & 0.752 & 0.505 \\
\hline \multicolumn{3}{|c|}{ Keluaran Layanan Karyawan: } \\
\hline $\mathrm{KO}$ & 0.827 & 0.547 \\
\hline EDC & 0.879 & 0.786 \\
\hline KK & 0.911 & 0.773 \\
\hline Kinerja Bisnis & 0.937 & 0.750 \\
\hline
\end{tabular}

Berdasarkan Tabel 3, ternyata hanya elemen pemberdayaan karyawan (PK) yang mempunyai skor construct reliability $<0.70$ dan variabel-variabel yang lain telah memiliki skor construct reliability $>0.70$. Hasil-hasil ini menunjukkan bahwa setiap konstruk telah memenuhi persyaratan reliabilitas (Hair et al., 1998; Nunally \& Bernstein, 1994, dalam Ferdinand, 2002).

Sedangkan, elemen perlakuan pelanggan (PP) dan pemberdayaan karyawan (PK) menunjukkan hasil-hasil variance-extracted yang nilainya $<0.5$, artinya hanya antara $30 \%-40 \%$ varians diantara indikator-indikator pengukuran dapat menjelaskan setiap konstruknya. Seluruh konstruk tetap dipertahankan meski terdapat beberapa elemen/dimensi yang memiliki variance-extracted $<0.5$, karena: (1) data penelitian disajikan apa adanya, (2) ukuran ini bersifat pelengkap saja bagi reliabilitas konstruk, dan (3) hanya pada uji variance-extracted saja yang menunjukkan hasil kurang baik, sedangkan untuk uji validitas dan reliabilitas pada hampir semua konstruk telah memenuhi syarat.

\section{Pemenuhan Asumsi-Asumsi SEM}

Hasil uji atas asumsi-asumsi yang mendasari analisis SEM menunjukkan hasil yang baik, kecuali asumsi normalitas yang menunjukkan bahwa baik secara univariat dan multivariate, data sampel terdistribusi secara tidak normal. Data tidak normal tetap digunakan karena disajikan apa adanya dan tidak dilakukan upaya transformasi data, karena akan menimbulkan kesulitan intertpretasi data setelah berbentuk data yang baru (Tabahnick \& Fidel, 1996).

\section{Two-Step Model-Building Approach}

Pada Tabel 4 ditunjukkan hasil perhitungan construct-reliability $(\alpha)$, error $(\varepsilon)$, dan lambda $(\lambda)$ terms.

Tabel 4. Construct-reliability, Error dan Lambda Terms Setiap Faktor

\begin{tabular}{cccc}
\hline Konstruk & $\begin{array}{c}\text { Construct } \\
\text { Reliability }(\boldsymbol{\alpha})\end{array}$ & Lambda $(\boldsymbol{\lambda})$ & Error $(\boldsymbol{\varepsilon})$ \\
\hline OL: & 0.797 & 0.707 & 0.127 \\
VL & 0.870 & 0.865 & 0.112 \\
KL & 0.715 & 0.578 & 0.133 \\
PP & 0.648 & 0.379 & 0.078 \\
PK & 0.834 & 0.745 & 0.111 \\
GL & 0.748 & 0.734 & 0.181 \\
PL & 0.838 & 1.024 & 0.202 \\
TL & 0.733 & 0.609 & 0.135 \\
PKL & 0.883 & 0.945 & 0.118 \\
RKL & 0752 & 0.373 & 0.046 \\
KSL & & & \\
KLK: & 0.827 & 0.725 & 0.110 \\
KO & 0.879 & 1.228 & 0.208 \\
EDC & 0.911 & 1.203 & 0.142 \\
KK & 0.937 & 0.617 & 0.026 \\
KB &
\end{tabular}

Sumber: Data primer, diolah 


\section{Evaluasi Kriteria Goodness of Fit}

Berdasarkan komputasi Amos 16, untuk model persamaan struktural yang diajukan, dihasilkan indeks-indeks goodness of fit dan estimasi parameter (Tabel 5 dan Tabel 6).

Pada Tabel 5 dan 6 menunjukkan bahwa hampir semua kriteria yang digunakan memiliki nilai yang marginal. Hal ini dapat dilihat pada nilai indeks goodness of fit indices yang mana hanya nilai RMSEA yang baik. Hasil GFI ini tetap dapat digunakan karena sedikit di bawah batasan yang telah ditetapkan di mana berdasarkan kesepakatan para peneliti bahwa cut-off value tersebut benar-benar digunakan untuk membedakan model yang baik dengan model yang marginal (Hair et al., 1998). Namun, semua nilai $C R$ dalam Tabel 6 adalah signifikan, sehingga konsisten dengan teori yang mendasarinya. Dengan demikian, model dalam studi ini dapat dianggap mampu menunjukkan tanda dan ukuran yang benar serta konsisten dengan teori yang mendasarinya.

Berdasarkan hasil analisis atas model-model yang diajukan dapat diketahui bahwa seluruh hipotesis $(\mathrm{H} 1, \mathrm{H} 2$ dan $\mathrm{H} 3)$ dinyatakan diterima atau didukung oleh data sampel dengan mengacu ke nilainilai loading factor dan probabilitasnya. Loading factor tersebut signifikan pada $p<0.05$ atau $p<0.01$ dan dapat disimpulkan bahwa hipotesis yang menyatakan loading factor sama dengan nol dapat ditolak. Oleh karena itu, unidirectional path dari OL menuju KLK (H1), dari strategi OL menuju KB (H2), dan dari KLK ke KB (H3) dapat dinyatakan signifikan.

Table 5. Evaluasi Kriteria Goodness of Fit Indices Model yang Diajukan

\begin{tabular}{llll}
\hline \multicolumn{1}{c}{ Kriteria } & $\begin{array}{c}\text { Nilai } \\
\text { Kritis }\end{array}$ & $\begin{array}{c}\text { Hasil } \\
\text { Model Ini }\end{array}$ & \multicolumn{1}{c}{ Keterangan } \\
\hline Chi-Square $\left(\chi^{2}\right)$ & Kecil & 198.853 & $\begin{array}{l}\text { Diharapkan nilainya } \\
\text { kecil }\left(\chi_{\text {tabel }}^{2}=96.217\right)\end{array}$ \\
Derajat Bebas $(d f)$ & Positif & 76 & $\begin{array}{l}\text { Positif } \\
\text { Significance }\end{array}$ \\
Probability & $\geq 0.05$ & 0.000 & Marginal \\
$\chi^{2}$ relatif $(\mathrm{CMIN} / \mathrm{DF})$ & $\leq 2.00$ & 2.616 & Marginal \\
GFI & $\geq 0.90$ & 0.802 & Marginal \\
AGFI & $\geq 0.90$ & 0.727 & Marginal \\
TLI & $\geq 0.90$ & 0.865 & Marginal \\
CFI & $\geq 0.90$ & 0.887 & Marginal \\
RMSEA & $\leq 0.80$ & 0.114 & Baik \\
\hline
\end{tabular}

Sumber: Data primer, diolah
Tabel 6. Estimasi Parameter untuk Model yang Diajukan

\begin{tabular}{|c|c|c|c|c|c|c|c|}
\hline & & & Estimate & S.E. & C.R. & $\mathbf{P}$ & Label \\
\hline KLK & <-- & OL & 0.807 & 0.258 & 5.302 & $* * *$ & $\overline{\text { par_12 }}$ \\
\hline VL & $<--$ & OL & 0.933 & 0.069 & 10.184 & $* * *$ & par \\
\hline KL & $<--$ & OL & 0.888 & 0.069 & 10.732 & **** & par \\
\hline PP & $<--$ & OL & 0.953 & 0.069 & 7.607 & **** & par \\
\hline PK & $<--$ & OL & 0.93 & 0.084 & 7.989 & *** & par_4 \\
\hline GL & $<--$ & OL & 0.954 & 0.072 & 11.667 & *** & par_ \\
\hline PL & $<--$ & OL & 1 & 0.073 & 10.774 & **** & par_ \\
\hline TL & $<--$ & OL & 0.752 & 0.069 & 7.838 & **** & par_7 \\
\hline PKL & $<--$ & OL & 0.723 & 0.074 & 5.979 & **** & par_8 \\
\hline RKL & $<--$ & OL & 0.929 & 0.067 & 11.751 & **** & par_9 \\
\hline KSL & $<--$ & OL & 0.972 & 0.074 & 10.281 & $* * *$ & par_10 \\
\hline KB & $<--$ & OL & 0.424 & 0.13 & 2.752 & 0.006 & par_11 \\
\hline KB & $<--$ & KLK & 0.429 & 0.077 & 2.785 & 0.005 & par_13 \\
\hline $\mathrm{KO}$ & $<--$ & KLK & 0.868 & 0.056 & 5.965 & $* * *$ & par_14 \\
\hline EDC & $<--$ & KLK & 0.655 & 0.056 & 5.879 & **** & par_15 \\
\hline KK & $<--$ & KLK & 0.882 & 0.057 & 6.349 & $* * *$ & par_16 \\
\hline
\end{tabular}

\section{Model Struktural Hasil Penelitian}

Gambar 2 menunjukkan model persamaan struktural yang dihasilkan dari olah data dengan menggunakan pendekatan komposit.

Model ini telah menunjukkan estimasi parameter dengan tanda dan ukuran yang benar (plausible) dan konsisten dengan teori yang mendasarinya. Goodness of fit indices model hasil penelitian di atas dapat dilihat pada Tabel 5 , meski hampir semua kriteria goodness of fit memiliki nilai yang marginal. Namun model masih dapat diterima, dan pengujian model ini menghasilkan konfirmasi yang baik atas faktor-faktor penelitian dan hubunganhubungan kausalitas antar faktor. Keadaan ini juga mengindikasikan bahwa data sampel juga fit dengan model yang dihipotesiskan.

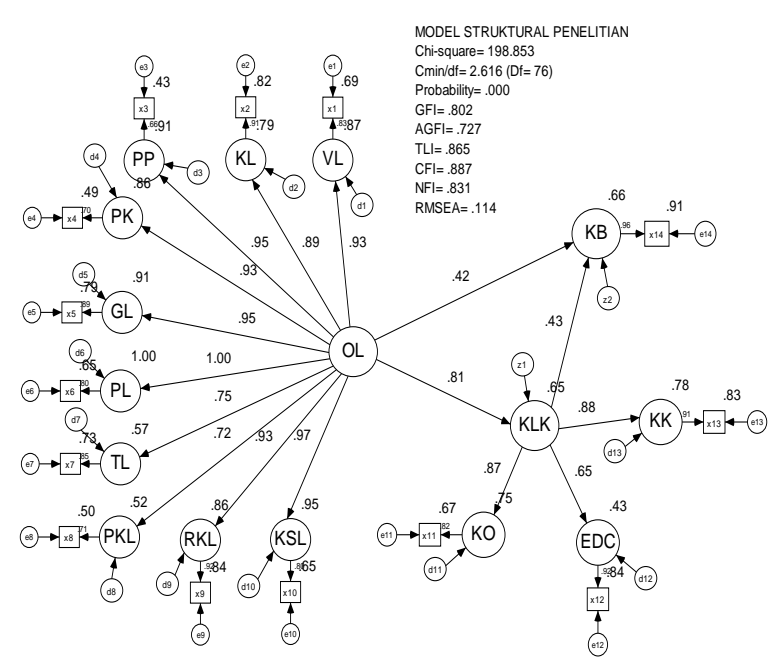

Gambar 2. Model Struktural Hasil Penelitian 


\section{Analisis Efek Langsung, Efek Tak Langsung dan Efek Total}

Untuk menganalisis efek langsung, efek tak langsung dan efek total antar konstruk, pedomanpedoman berikut ini dapat digunakan. Efek langsung tidak lain adalah koefisien dari semua garis koefisien dengan anak panah satu ujung. Efek tak langsung adalah efek yang muncul melalui sebuah vaiabel antara. Efek total adalah efek dari berbagai hubungan. Analisis atas ketiga jenis efek tersebut dapat dilihat berturut-turut pada Tabel 7, 8 dan 9 .

Ketiga tabel di atas menunjukkan bahwa terdapat efek langsung dari variabel OL terhadap variabel KLK sebesar 0.807, efek langsung dari variabel OL terhadap variabel KB sebesar 0.424, dan efek langsung dari variabel KLK terhadap variabel KB sebesar 0.429. Selanjutnya, efek tak langsung dari variabel OL melalui variabel KLK terhadap variabel KB sebesar 0.346. Sedangkan efek total dari variabel OL terhadap variabel KLK sebesar 0.807 (sama besar dengan efek langsungnya). Efek total dari variabel OL terhadap variabel $\mathrm{KB}$ sebesar 0.77. Efek total variabel KLK terhadap variabel KB sebesar 0.429.

Tabel 7. Standardized Total Effect - Estimates

\begin{tabular}{ccc}
\hline & OL & KLK \\
\hline KLK & 0.807 & \\
KB & 0.77 & 0.429 \\
\hline Sumber: Data primer, diolah & &
\end{tabular}

Tabel 8. Standardized Direct Effect - Estimates

\begin{tabular}{lcc}
\hline & OL & KLK \\
\hline KLK & 0.807 & \\
KB & 0.424 & 0.429 \\
\hline
\end{tabular}

Sumber: Data primer, diolah

Tabel 9. Standardized Indirect Effect - Estimates

\begin{tabular}{ccc}
\hline & OL & KLK \\
\hline KLK & \\
KB & 0.346 & \\
\hline Sumber: Data primer, diolah & &
\end{tabular}

\section{Pembahasan}

Hasil evaluasi indeks goodness of fit atas model struktural hasil penelitian menunjukkan hasil yang marginal (Tabel 5). Meski demikian, model dapat diterima dan hasil-hasilnya telah mengkonfirmasi studi-studi sebelumnya. Secara umum, data sampel memberikan hasil yang mendukung model persamaan struktural untuk kinerja bisnis lembaga pendidikan tinggi.
Hubungan antara Orientasi Layanan dan Keluaran Layanan Karyawan

Orientasi layanan sebagai bagian dari budaya organisasi perlu mendapatkan perhatian serius karena memengaruhi tingkat motivasi serta komitmen contact employees (dosen dan administrasi) dalam menjalani pekerjaannya. Sikap dan perilaku mereka dapat memengaruhi persepsi mutu layanan dan kepuasan pelanggan (Lee et al., 2000). Daya tanggap contact employees sangat terkait dengan budaya organisasi dalam memberikan layanan secara prima. Oleh karena itu, perusahaan jasa yang umumnya berbentuk people-based service companies, seharusnya meningkatkan daya tanggap karyawannya dengan cara memperbaiki motivasinya, keahlian layanannya, pelatihan sikap, persepsi peran yang lebih jelas, dan pengetahuan tentang layanan itu sendiri serta kebijakan-kebijakan organisasi. Hasilnya, mereka diharapkan akan meningkatkan mutu layanan, yang juga memiliki arti peningkatkan kinerja bisnis organisasi (Lee et al., 2000).

Pemahaman ini merefleksikan bahwa iklim dan orientasi harus dapat diciptakan melalui interaksi kebijakan, praktek dan prosedur yang menciptakan perasaan, predisposisi, dan/atau orientasi organisasi (Schein, 1968; Pettigrew, 1979; Uttal, 1983; Deshpande \& Webster, 1989; Hofstede et al., 1990; Schein, 1985; Schneider \& Bowen, 1993; Schneider \& Bowen, 1995; Schneider et al., 1996; Schneider et al., 1992) dan benar dirasakan serta diapresiasi oleh karyawan. Evaluasi orientasi layanan akan lebih baik ketika kesimpulan karyawan umumnya berpusat di sekitar bagaimana organisasi menunjukkan pekerjaan sehari-harinya dan tujuan-tujuan apa saja yang dikejar oleh organisasi. Kesimpulan-kesimpulan ini "didasarkan pada kebijakan, praktik, prosedur dan rutinitas yang karyawan untuk tunduk dan dalam jenis perilaku yang diharapkan dan Anda mendapatkan imbalan dan didukung" (Schneider et al., 1996).

Persepsi karyawan dan kesimpulan mereka, termasuk citra kualitas layanan, menjadi semakin penting untuk studi bisnis karena akan lebih mencerminkan iklim nyata organisasi yang benar dan karena terkait dengan kinerja organisasi (Benoy, 1996, Hallowell et al., 1996; Johnson, 1996 dan Schneider dan Bowen, 1995). Hasil-hasil dari studi empiris yang menunjukkan bahwa karyawan yang mempersepsikan organisasinya sebagai "memiliki orientasi pelayanan yang kuat, memiliki pelanggan yang mau menyatakan bahwa pelanggan memiliki pengalaman yang positif dengan organisasi" (Heskett et al., 1997; Schneider \& Bowen 1993). 
Temuan ini memperkuat pandangan bahwa persepsi mutu oleh pelanggan merupakan fungsi adanya "fakta mutu dan persepsi mutu", sehingga keduanya menjadi isu sikap dan keyakinan yang berkaitan dengan kesadaran (awareness) dan pengakuan (recognition), kepuasan pelanggan serta perilaku konsumen (Andreassen \& Lindestad, 1998). Dalam konteks jasa, proses penyampaian layanan melibatkan penyedia dan pembeli jasa. Interaksi keduanya akan menentukan persepsi mutu, kepuasan pelanggan serta perilaku pelanggan selanjutnya atas interaksi yang terjadi.

Dengan demikian, elemen kepuasan kerja dosen/karyawan, elemen esprit de corps dan elemen komitmen organisasi perlu dipelihara dengan melakukan upaya-upaya perbaikan dalam interaksi kebijakan, praktek dan prosedur yang menciptakan perasaan, predisposisi, dan/atau orientasi organisasi. Artinya, keterkaitan ketiga elemen tersebut dalam perbaikan dan peningkatan keluaran layanan karyawan akan memberikan dampak pengelolaan tingkat kepuasan dosen/karyawan atas pekerjaannya dan dapat mendorong perbaikan efisiensi dalam pekerjaan. Keadaan ini akan terwujud ketika karyawan merasa menikmati pekerjaannya, mendapat kepuasan yang adil dengan pekerjaannya, antusias dalam pekerjaan setiap harinya dan menemukan kesenangan yang berarti dalam pekerjaannya.

Selain itu, kepuasan kerja seseorang ditentukan oleh tantangan kerja yang ada, prosedur/ganjaran yang adil, kondisi kerja yang baik dan dukungan dari kolega. Artinya, kepuasan kerja berkaitan dengan kebutuhan fisiologikal atau psikologikal yang ingin dipenuhi. Jika tidak terpenuhi, maka persepsi ketidakpuasan akan cenderung meningkatkan ketegangan dan dorongan untuk berperilaku tidak efektif (Robbins, 2005). Akibatnya, keadaan ini dapat mendorong munculnya persepsi tentang rendahnya sikap kerja positif dosen/karyawan dalam melayani mahasiswa, mahasiswa kurang merasa nyaman ketika berurusan dengan dosen, serta agak kesulitan mendapatkan layanan dalam rentang waktu yang dapat diterima (Yuniawan, 2009).

Di sisi lain, elemen komitmen organisasi mampu menunjukkan perannya terhadap pembentukan keluaran layanan karyawan melalui sikap dosen/karyawan yang menganggap bahwa masa depan mereka sangat terkait dengan masa depan lembaga ini, kesediaan berkorban bagi kesejahteraan unit kerjanya, memiliki Ikatan yang kuat dengan organisasi, dan bangga bekerja dalam lembaga ini. Sedangkan, untuk elemen esprit de corps, dosen/ karyawan telah menunjukkan pandangan bahwa orang-orang di unit kerjanya benar-benar peduli satu sama lain tentang kebutuhan dan masalah mereka, semangat tim telah menjiwai semua tingkatan dalam unit kerjanya, merasa bahwa bekerja untuk unit kerja ini seperti menjadi bagian dari keluarga besar, dan orang-orang di unit kerjanya merasa terikat secara emosional satu sama lain.

Dengan demikian, temuan-temuan dalam studi ini cukup memberikan peringatan bagi perguruan tinggi untuk benar-benar memperhatikan sikap dan persepsi dosen/karyawannya dalam menjalankan praktek bisnisnya. Langkah ini diharapkan mampu meningkatkan daya tanggap karyawannya melalui perbaikan motivasinya, keahlian layanannya, pelatihan sikap, persepsi peran yang lebih jelas, dan pengetahuan tentang layanan itu sendiri serta kebijakankebijakan organisasi. Hasilnya, mereka diharapkan akan meningkatkan citra mutu layanan, yang sebenarnya juga memiliki arti adanya peningkatkan kinerja bisnis.

\section{Hubungan antara Orientasi Layanan dan Kinerja Bisnis}

Hasil ini konsisten dengan kajian Gilbert \& Parhizgary (2000) yang menyatakan bahwa kompleksitas dan persaingan lingkungan bisnis yang makin kuat telah "memaksa" organisasi untuk meningkatkan kinerja/efektivitasnya. Caranya adalah dengan memiliki struktur dan proses internal organisasi yang terfokus pada mutu, termasuk mendukung kualitas dan kinerja karyawan lini depan. Mereka adalah ujung tombak organisasi yang dapat membangun atau sebaliknya merusak citra dan reputasi organisasi terhadap pelanggannya.

Citra institusional terkait dengan berbagai atribut fisik dan keperilakuan suatu organisasi. Misalnya: nama bisnis, arsitektur organisasi, variasi produk/ layanan, tradisi, ideologi, dan kesan mutu setiap orang yang berinteraksi dengan klien organisasi. Sedangkan, reputasi institusional adalah cerminan sejarah kinerja organisasi yang berfungsi sebagai bentuk komunikasi organisasi dengan kelompok targetnya. Misalnya: kinerja mutu produk/layanan organisasi dibandingkan dengan pesaingnya (Nguyen \& LeBlanc, 2001). Temuan $\mathrm{H} 2$ yang didukung oleh data telah memberi bukti bahwa organisasi perguruan tinggi telah mampu meningkatan orientasi layanannya, sehingga mampu meningkatkan kinerja organisasi. Temuan ini sejalan dengan temuan (Homburg et al., 2002; Kohli \& Jaworski, 1990; Narver \& Slater, 1990; Lyle et al., 2000).

Hasil ini memberi juga gambaran bahwa organisasi telah mampu meningkatkan kesiapan rencana kegiatan organisasi yang berbasis layanan, 
meningkatkan keterlibatan proaktif dan menghargai prkatek-praktek penyampaian layanan, proses dan prosedur yang merefleksikan keyakinan bahwa keprimaan layanan adalah suatu prioritas strategik. Organisasi juga dianggap telah dapat meningkatkan keyakinan bahwa ketika orientasi layanan dapat dimanifestasikan ke dalam layanan prima, maka hal ini akan berdampak signifikan dalam penciptaan nilai superior, kepuasan pelanggan, keunggulan kompetitif, pertumbuhan dan profitabilitas. Orientasi layanan dapat dipandang sebagai respon strategis terhadap intelijensi pasar-cara tertentu dalam implementasi konsep pemasaran, bersaing dengan penggunaan layanan prima untuk meningkatkan nilai pelanggan dan keunggulan kompetitif. Selain itu, organisasi juga mampu menjalankan orientasi layanan organisasional sebagai suatu serangkaian kebijakan, praktek dan prosedur organisasi yang ditujukan untuk mendukung dan menghargai perilaku penyampaian layanan yang menciptakan dan memberikan layanan prima (Lytle $e t$ al., 1998).

Dengan demikian, organisasi sudah mampu menjamin bahwa indikator-indikator orientasi layanan dalam internal organisasi telah dapat dijalankan dan lembaga pendidikan tinggi sudah memiliki kemampuan yang baik dan mampu secara kuat menunjukkan kinerjanya dalam: 1) mutu layanan lembaga ini lebih baik dari lembaga lainnya, 2) lebih memuaskan dibandingkan lembaga lainnya, 3) menunjukkan kesan yang baik tentang organisasi ini, 4) menunjukkan citra yang baik di benak pelanggannya (baca: mahasiswa), dan 5) citra yang lebih baik dari pesaingnya. Keluaran-keluaran organisasional seperti profit, pertumbuhan, kepuasan pelanggan, kepuasan dan loyalitas karyawan diakui sebagai keluaran orientasi layanan organisasional (Albrecht \& Zemke, 1985; Heskett et al., 1997; Henkoff, 1994; Johnson, 1996; O'Connor \& Shewchuk, 1995; Rust et al., 1996; Sasser \& Jones, 1995; Schneider \& Bowen, 1995). Agaknya, pemahaman atas temuan studi ini cukup memberikan gambaran bahwa upaya peningkatan orientasi layanan organisasi harus tetap dijaga untuk meningkatkan kinerja bisnis. Organisasi perguruan tinggi perlu melakukan langkah-langkah berkelanjutan untuk memelihara citra, reputasi dan mutu layanannya dengan tetap secara kuat memperhatikan kebutuhan-kebutuhan dan harapan-harapan berbagai kelompok yang berinteraksi dengannya, terutama pelanggan utamanya.

Oleh karena itu, perguruan tinggi perlu memanfaatkan manajemen mutu (TQM) karena diketahui memiliki nilai-nilai yang lebih cocok daripada sistem manajemen lainnya. TQM dipandang memiliki banyak potensi untuk merespon tantangan sistem pendidikan serta dapat diaplikasikan sebagai sarana untuk memperbaiki moral staf/mahasiswa, produktivitas, dan penyampaian mutu layanan lebih tinggi baik untuk pelanggan internal maupun eksternal (Owlia \& Aspinwall, 1997).

Perguruan tinggi sebaiknya mampu melihat TQM sebagai jawaban untuk memperoleh kembali dan memperkuat keunggulan kompetitifnya sebagaimana yang telah dilakukan oleh industri manufaktur (Motwani \& Kumar, 1997) dan beberapa institusi pendidikan Kwan (1996). Mereka mampu mengadopsi kerangka TQM yang relevan dengan misi dan tujuan organisasi serta dibangun berdasarkan serangkaian nilai dan konsep manajemen mutu agar dapat memberikan fondasi untuk integrasi persyaratan kinerja kunci dalam kerangka mutu. Serangkaian nilai fundamental yang digunakan dalam kerangka TQM di lembaga pendidikan tinggi adalah a) kepemimpinan dan budaya mutu, b) perbaikan berkelanjutan dan inovasi dalam proses pendidikan, c) partisipasi dan pengembangan karyawan, d) respon cepat dan manajemen informasi, e) mutu berbasis pelanggan, dan f) kerjasama pengembangan secara internal dan eksternal (Venkatraman, 2007). Implementasi kerangka TQM dalam pendidikan tinggi menuntut adanya proses pengelolaan pendidikan yang saling terkait, kompleks, dan meliputi berbagai dimensi mutu. Tuntutan lainnya adalah kolaborasi dengan perusahaan, daya respon terhadap informasi, fasilitas/sumberdaya pendidikan dan non-pendidikan yang tersedia, praktek-praktek evaluasi dan pengajaran, serta tipe kuliah yang ditawarkan.

Keberhasilan perguruan tinggi dalam mengelola pengembangan pendidikan tinggi yang baik akan meningkatkan kemampuannya menghadapi masa depan yang penuh tantangan, laju perubahan yang cepat, tuntutan masyarakat yang lebih maju, kehidupan yang sangat dipengaruhi oleh perkembangan ilmu pengetahuan dan teknologi, serta globalisasi (Yuniawan, 2009). Perlu disadari bahwa paradigma baru dalam pendidikan tinggi telah meminta adanya pendekatan yang benar-benar baru di mana isu-isu pendidikan berskala besar, life-long learner, open learning, mutu dan relevansi, akuntabilitas dan autonomi, serta keadilan yang menjadi begitu penting untuk diwujudkan. Dampak globalisasi telah menyebabkan pergeseran peran institusi pendidikan tinggi dari institusi pembelajaran tradisional menuju institusi pencipta pengetahuan, yang menuntut sebuah perubahan dari perencanaan acak menuju perencanaan strategik (Ditjen Dikti, 2004).

\section{Hubungan antara Keluaran Layanan Karyawan dan Kinerja Bisnis}

Temuan ini memperkuat pandangan bahwa persepsi keluaran layanan karyawan dapat menjadi 
isu sikap, keyakinan, dan perilaku yang berkaitan dengan kesadaran (awareness) dan pengakuan (recognition) atas kinerja mereka selama ini. Dalam konteks jasa, proses penyampaian layanan melibatkan penyedia dan pembeli jasa. Interaksi keduanya akan menentukan persepsi mutu, kepuasan pelanggan serta perilaku pelanggan selanjutnya atas interaksi yang terjadi. Ketika hal-hal tersebut mampu diwujudkan, maka dalam jangka panjang, kinerja bisnis akan dapat dipelihara dengan lebih baik karena mampu menunjukkan citra mutu layanan yang baik.

Perlu diketahui, terbentuknya citra dan/atau reputasi suatu organisasi dalam benak konsumen adalah proses yang panjang. Oleh karena itu, organisasi perlu menjaga bahwa proses sensori (tentang ideide, perasaan dan pengalaman hubungan antara pelanggan dan perusahaan-yang direpresentasikan oleh sikap dan perilaku para karyawan) yang kemudian terbentuk dalam suatu gambaran mental di benak pelanggan harus dapat diwujudkan dengan baik. Dalam jangka panjang, pelanggan akan memiliki sikap yang terakumulasi tentang mutu layanan dan perusahaan. Artinya, pelanggan mengembangan suatu sistem (misal: skema diri) dalam benaknya untuk menginterpretasikan persepsi tentang pengalamannya berhubungan dengan perusahaan dan mempengaruhi keputusan pembelian pelanggan (Markus, 1977 dalam Andreassen \& Lindestad, 1998).

Literatur manajemen menunjukkan bahwa mutu dalam internal organisasi yang ditunjukkan melalui keluaran layanan karyawan dapat meningkatkan produktivitas dan menurunkan biaya-biaya internal, sehingga meningkatkan profitabilitas secara tidak langsung. Penyesuaian suatu produk/jasa yang melampui kebutuhan-kebutuhan pelanggan akan meningkatkan kepuasan pelanggan, dan selanjutnya, peningkatan hasil bisnis (Gustafsson, et al., 2003). Pernyataan ini memperkuat pendapat bahwa organisasi yang efektif mensyaratkan adanya struktur dan proses internal yang baik agar dapat menunjukkan mutu layanan yang terpelihara bagi pelanggan eksternal dari waktu ke waktu. Studi Zifko-Baliga \& Kramf (1997) dalam Bendall-Lyon \& Powers (2004) menunjukkan bahwa pelanggan memiliki standar normatif tentang aspek-aspek yang berbeda dari suatu layanan dan sering menilai kepuasannya dalam aspek struktur dan proses. Literatur juga menunjukkan bahwa struktur dan proses mempengaruhi kepuasan yang selanjutnya mempengaruhi niatan perilaku (Hennig-Thurau, 2001 dalam Bendall-Lyon \& Powers, 2004). Dengan demikian, untuk membangun hubungan (jangka panjang) yang kuat, perguruan tinggi harus "mampu" memberikan jaminan bahwa pelanggan utamanya sangat puas (highly satisfied) dengan proses pendidikan yang diberikannya. Apalagi, terdapat konsensus di antara praktisi dan akademisi bahwa kepuasan pelanggan dan mutu layanan juga menjadi prasyarat tumbuhnya loyalitas (Gremler \& Brown, 1997 dalam Kandampully \& Suhartanto, 2000; Cronin \&Taylor, 1992).

\section{KESIMPULAN DAN SARAN}

\section{Kesimpulan}

Studi ini telah menguji suatu model yang mendefinisikan hubungan struktural diantara konstrukkonstruk yang relevan dengan kinerja bisnis pada lembaga pendidikan tinggi. Hasil evaluasi goodness of fit indices atas model struktural yang diajukan telah menunjukkan hasil yang marginal. Namun, hasil evaluasi besaran dan arah hubungan antar variabel telah menunjukkan arah dan tanda yang benar serta mampu mengkonfirmasi temuan-temuan sebelumnya. Hasil penelitian juga memberi perspektif baru dalam pendekatan analisis yang mana pendekatan analisis sebelumnya menggunakan pendekatan deskriptif korelasional. Secara umum, data sampel mendukung model persamaan struktural untuk kinerja bisnis yang diajukan dalam studi ini.

Berdasarkan hasil-hasil analisis dalam studi ini, studi ini dapat menunjukkan sejumlah temuan yang terkait pengelolaan organisasi, termasuk bagi lembaga-lembaga pendidikan tinggi, dengan memberi perhatian atas variabel-variabel yang menjadi perhatian dalam studi, yaitu:

1. Orientasi Layanan. Temuan studi menunjukkan bahwa peningkatan orientasi layanan organisasi pendidikan tinggi mampu meningkatkan keluaran layanan karyawan. Artinya, dapat disimpulkan bahwa $H I$ didukung oleh data sampel. Artinya, secara internal terbukti bahwa terdapat upaya peningkatan orientasi layanan yang telah membawa dampak pada peningkatan keluaran layanan karyawan. Oleh karena itu, orientasi layanan sebagai bagian dari budaya organisasi perlu dipelihara secara serius, karena memengaruhi tingkat motivasi serta komitmen contact employees (dosen dan administrasi) dalam menjalani pekerjaannya.

\section{Kinerja Bisnis}

Temuan studi menunjukkan bahwa peningkatan orientasi layanan organisasi pendidikan tinggi mampu meningkatkan kinerja bisnis. Artinya, dapat disimpulkan bahwa $H 2$ didukung oleh data sampel. Temuan ini mendukung bahwa organisasi perguruan tinggi telah mampu meningkatan orientasi layanannya, sehingga mampu mening- 
katkan kinerja organisasi. Perbaikan kinerja ini telah didukung dengan kesiapan rencana kegiatan organisasi yang berbasis layanan, meningkatkan keterlibatan proaktif dan menghargai praktekpraktek penyampaian layanan, proses dan prosedur yang merefleksikan keyakinan bahwa keprimaan layanan adalah suatu prioritas strategik, termasuk mewujudkannya dalam layanan prima yang dapat berdampak signifikan dalam penciptaan nilai superior, kepuasan pelanggan, keunggulan kompetitif, pertumbuhan dan profitabilitas.

3. Keluaran karyawan.

Temuan studi menunjukkan bahwa peningkatan keluaran layanan karyawan mampu meningkatkan kinerja bisnis. Artinya, dapat disimpulkan bahwa $H 3$ didukung oleh data sampel. Temuan ini memperkuat pandangan bahwa persepsi keluaran layanan karyawan dapat menjadi isu sikap, keyakinan dan perilaku yang berkaitan dengan kesadaran (awareness) dan pengakuan (recognition) atas kinerja mereka selama ini. Proses penyampaian layanan melibatkan penyedia dan pembeli jasa. Interaksi keduanya dapat menentukan persepsi mutu, kepuasan dan perilaku pelanggan selanjutnya atas interaksi yang terjadi. Tujuan yang ingin dicapai dalam jangka panjang adalah kinerja bisnis dapat dipelihara dan tetap mampu menunjukkan citra mutu layanan yang baik.

\section{Keterbatasan Studi}

Studi ini memiliki keterbatasan-keterbatasan, antara lain: 1) studi ini hanya dilakukan pada satu lembaga pendidikan tinggi meski pun telah melibatkan informan internal yang berbeda (karyawan dan dosen). Artinya, belum dapat dijamin bahwa hasilhasil studi ini akan dapat ditransfer dengan baik untuk tipe-tipe industri yang lain, 2) studi ini belum mencoba melihat perbedaan analisis antara persepsi karyawan dan dosen serta masih menggunakan data cross-section untuk melihat kinerja bisnis suatu organisasi, dan 3) studi ini dianalisis dengan pendekatan komposit atau dengan variable-to-sample size ratio yang minimal. Padahal, studi ini memerlukan jumlah data yang lebih besar untuk kebutuhan analisis daripada jumlah data yang telah diolah.

\section{Saran-saran}

Studi ini telah menemukan sejumlah hal yang perlu diperhatikan dan penting artinya bagi perbaikan hasil-hasil dimasa datang baik dari sisi teoritis mau pun manajerial. Secara ringkas, hal-hal tersebut diuraikan sebagai berikut:

\section{Penelitian Mendatang}

Berdasarkan keterbatasan yang ada dalam studi ini, terdapat tiga rencana yang dapat diberikan untuk penelitian mendatang. Pertama, penelitian mendatang sebaiknya menggunakan lebih banyak lembaga pendidikan dalam satu tipe industri yang sama atau organisasi yang berbeda dalam tipe industri yang berbeda untuk mendapatkan hasil yang lebih komprehensif dan bermakna luas. Kedua, Penelitian mendatang sebaiknya melihat perbedaan analisis antara persepsi karyawan dan dosen agar dapat lebih memperkaya hasil analisis dan interpretasinya untuk pemahaman yang lebih baik atas model studi yang diajukan. Selain itu, penggunaan data longitudinal sangat disarankan, meski data cross-section banyak dilakukan untuk metodologi yang sama dalam risetriset pemasaran strategik dan manajemen lainnya. Ketiga, penelitian mendatang sebaiknya meningkatkan jumlah data hingga jumlahnya ideal atau dengan variable-to-sample size ratio yang dapat diterima.

\section{Implikasi Manajerial}

Studi ini telah mencoba memahami aspek-aspek manajemen pemasaran, SDM, dan perilaku organisasi. Selain itu, dengan memperhatikan temuantemuan dalam studi ini, maka dapat disampaikan saran-saran dalam sejumlah hal berikut:

a. Temuan studi ini menunjukkan bahwa orientasi layanan mempengaruhi keluaran layanan karyawan (KLK), dimana semua elemen KLK menunjukkan arah dan besaran yang benar. Artinya, orientasi layanan telah mampu membangkitkan komitmen, rasa esprit de corps dan kepuasan kerja yang baik dalam organisasi. Misalnya, esprit de corps (EDC) dapat dijadikan sebagai bahan penting dalam penyampaian mutu layanan, karena dapat menjadi instrumen yang baik dalam menekan gap, antara spesifikasi mutu layanan dan pelayanan aktual, sehingga dapat memperbaiki persepsi pelanggan. EDC juga dapat dijadikan sebagi aspek penting budaya organisasi, sehingga perlu dimonitor agar memberikan dampak yang baik bagi praktek kerja karyawan, mutu layanan dan kepuasan pelanggan. Di sisi lain, komitmen organisasi dapat menuntun karyawan untuk merasa bangga bekerja dan menjadi bagian penting dalam organisasi. Ketika komitmen ini kuat, maka karyawan akan bersedia untuk bekerja ekstra bagi pelanggan organisasi dan berdampak pada produktivitas dan lamanya hubungan (longevity) dengan organisasi. Organisasi sebaiknya secara kuat mampu menunjukkan orientasi layanannya agar mampu menciptakan keluaran 
layanan karyawan yang terbaik dimana karyawan yang berkomitmen (dan mau bekerja dalam tim) akan cenderung bersedia mengembangkan hubungan jangka panjang dengan organisasi

b. Temuan dalam studi menunjukkan kebutuhan bagi manajemen untuk meningkatkan perhatian dalam upayanya meningkatkan dan memelihara citra mutu layanan yang dimiliki. Keberhasilan organisasi dalam menjalankan kefungsionalan perhatian manajemennya akan berdampak pada pencapaian keprimaan mutu layanan dan nilai pelanggan. Artinya, terdapat kebutuhan untuk membangun dan memelihara orientasi layanan sebagai bagian dari kemampuan manajemen dalam mengartikulasikan dan menyebarkan visi layanan yang mampu bertahan kuat, dapat diyakini dan memberikan motivasi. Selain itu, organisasi perlu meningkatkan proses service encounter aktualnya. Unit berkinerja tinggi umumnya memiliki karyawan yang mempunyai rasa tanggung jawab kuat untuk menjamin bahwa proses service encounter telah melampaui ekspektasi pelanggannya dan telah mendapatkan kewenangan dari manajemen untuk melakukan apa yang diperlukan guna mencapai kepuasan pelanggan. Agar hal ini terjaga dengan baik, organisasi juga perlu memberikan level pelatihan layanan tepat untuk meningkatkan pemberdayaan karyawan dan melengkapi mereka dalam menjalankan area-area pekerjaan yang menjadi tanggung jawabnya.

c. Organisasi sebaiknya mampu menjamin bahwa semua dimensi orientasi layanannya dapat dipahami dan berkembang dengan baik, melalui upaya-upaya yang membangun dan menumbuhsuburkan keberadaan orientasi layanannya melalui sosialisasi dan orientasi yang kuat atas visi, kepemimpinan, kebijakan, praktek dan prosedur yang dimiliki. Ketika hal ini mampu ditanamkan dan disebarkan dalam organisasi sebagai bagian dari budaya organisasi, dampaknya adalah munculnya kemampuan organisasi untuk menciptakan dan menyampaikan mutu layanan prima dan meningkatkan nilai pelanggan.

\section{DAFTAR PUSTAKA}

Albrecht, K. \& R. Zemke. 1985. Service America: Doing Business in the Service Economy, Homewood: Dow Jones-Irwin.

Aldrich, H. 1979. Organizations and Environments, Englewood Cliffs: Prentice-Hall.

Anderson, J.C. \& D.W. Gerbing. 1988. "Structural Equation Modeling in Practice: A Review and Recommended Two-Step Approach", Psychological Bullettin, page 411-423.
Andreassen, T.W. \& B. Lindestad. 1998. "Customer Loyalty and Complex Services: The Impact of Corporate Image on Quality, Customer Satisfaction, and Loyalty for Customers with Varying Degrees of Service Expertise". International Journal of Service Industry Management, page 7-23.

Bendall-Lyon, D. \& T.L. Powers. 2004. 'The Impact of Structure and Process Attributes on Satisfaction and Behavioral Intentions", Journal of Service Marketing, page 114-121.

Benoy, J. 1996. "Internal Marketing Builds Service Quality", Journal of Health Care Marketing, page 54-59.

Bourgeois, L.J. 1980. "Strategy and Environment: A Conceptual Integration", Academy of Management Review, page 25-39.

Bowen, D.E., C., Siehl \& B. Schneider. 1989. “A Framework for Analyzing Customer Service Organizations in Manufacturing", Academy of Management Review, page 75-95.

Chakravarthy, B.S. 1982. "Adaptation: A Promising Metaphor for Strategic Management", Academy of Management Review, page 35-44.

Chase, R.B. \& D.E. Bowen. 1991. Service Quality and The Service Delivery System: A Diagnostic Framework in Brown, S.W., Gummesson, E., Edvardsson, B. \& Gustavsson, B. (Eds), Service Quality: Multidisciplinary and Multinational Perspectives, Lexington: Lexington Books.

Conant, J.S., M.P. Mokwa \& P.R. Varadarajan. 1990. "Strategic Types, Distinctive Marketing Competencies and Organizational Performance: A Multiple Measure-Based Study", Strategic Management Journal, page: 365-383.

Cronin, J. \& S.A. Taylor. 1992. "Measuring Service Quality: A Reexamination and Extension", Journal of Marketing, page: 55-68.

Crosby, L. 1991. Building and Maintaining Quality in the Service Relationship in Brown, S.W., Gummesson, E., Edvardsson, B. \& Gustavsson, B. (Eds), Service Quality: Multidisciplinary and Multinational Perspectives, Lexington: Lexington Books: 269-288.

Day, G.S. 1990. Market Driven Strategy: Processes for Creating Value. New York: The Free Press,

Deal, T.E. \& A. Kennedy. 1982. Corporate Cultures: The Rites and Rituals of Corporate Life. Reading: Addison-Wesley. 
Deshpande, R. \& F.E. Webster. 1989. “An Organizational Culture and Marketing: Defining the Research Agenda", Journal of Marketing, page: 3-15.

Dilman, D.A. 1978. Mail and Telephone Surveys: The Total Design Method, New York: John Wiley and Sons.

Ditjen Dikti. 2004. Strategi Jangka Panjang Pendidikan Tinggi 2003-2010 (HELTS), Jakarta: Depdiknas Republik Indonesia.

Ferdinand, A. 2002. Structural Equation Modeling dalam Penelitian Manajemen, Edisi Kedua, Semarang: BP Undip.

Ferdinand, A. 2006. "Metode Penelitian Manajemen: Pedoman Penelitian Untuk Penulisan Skripsi", Tesis dan Disertasi Ilmu Manajemen, Semarang: BP Undip.

Gilbert, G.R. \& A.M. Parhizgary. 2000. "Organizational Effectiveness Indicators to Support Service Quality", Managing Service Quality, page: 46-51.

Gustafsson, A., L. Nilsson \& M.D. Johnson. 2003. "The Role of Quality Practices in Service Organization", International Journal of Service Industry Management, page: 232-244.

Hair, J.F., R.E. Anderson, R.L. Tatham \& W.C. Black. 1998. Multivariate Data Analysis, Fifth Edition. New Jersey: Prentice-Hall.

Hallowell, R., L. Schlesinger \& J. Zornitsky. 1996. "Internal Service Quality, Customer and Job Satisfaction: Linkages And Implications For Management", Human Resource Planning, page: 20-30.

Henkoff, R. 1994. "Service is Everybody's Business", Fortune, page: 48-60.

Heskett, J.L., E. Sasser \& L. Schlesinger. 1997. The Value Profit Chain: Treat Employees Like Customers and Customers like Employees, New York: Simon \& Schuster.

Hofstede, G., B. Neuijen, D. Ohayv, \& G. Sanders. 1990. "Measuring Organizational Cultures: A Qualitative and Quantitative Study Across 20 Cases". Administrative Science Quarterly, page: $286-316$.

Homburg, C., W. Hoyer \& M. Fassnacht. 2002. "Service Orientation of a Retailer's Business Strategy: Dimensions, Antecedents, and Performance Outcomes", Journal of Marketing, page: 86-101.
Jaworski, B.J. \& A.K. Kohli. 1993. "Market Orientation: Antecedents and Consequences", Journal of Marketing, page: 53-70.

Johnson, J.W. 1996. "Linking Employee Perceptions of Service Climate to Customer Satisfaction", Personnel Psychology, page: 831-851.

Kandampully, J. \& D. Suhartanto. 2000. "Customer Loyalty in The Hotel Industry: The Role of Customer Satisfaction and Image", International Journal of Contemporary Hospitality Management, page: 346-351.

Katz, D. \& R.L. Kahn. 1966. The Social Psychology of Organizations. New York: John Wiley and Sons.

Keats, B. \& M. Hitt. 1988. "A Causal Model of Linkages among Environmental Dimensions, Macro Organizational Characteristics, and Performance", Academy of Management Journal, page: $570-598$.

Kelley, S.W. 1992. "Developing Customer Orientation among Service Employees", Journal of the Academy of Marketing Science, page: 2736.

Kohli, A. \& B. Jaworski. 1990. "Market Orientation: The Construct, Research Propositions, and Managerial Implications", Journal of Marketing, page: 1-18.

Kwan, P.Y.K. 1996. "Application of Total Quality Management in Education: Retrospect and Prospect", International Journal of Educational Management, page: 25-35.

Lambert, D.M. \& T.C. Harrington. 1990. "Measuring Non-response Bias in Mail Surveys", Journal of Business Logistics, page: 5-25.

Lee, H., Y. Lee, \& D. Yoo. 2000. "The Determinant of Perceived Service Quality and Its Relationship with Satisfaction", Journal of Services Marketing, page: 217-231.

Lytle, R.S., P. Hom \& M.P. Mokwa. 1998. "SERVOR: A Managerial Measure of Organizational Service Orientation", Journal of Retailing, page: $455-489$.

Lytle, R.S., M. Lynn \& S. Bobek, 2000. "Service Orientation in Transitional Markets: Does It Matter?", European Journal of Marketing, page: $279-298$.

Motwani, J. \& A. Kumar. 1997. "The Need for Implementing Total Quality Management in Education", The International Journal of Educational Management, page: 131-135. 
Narver, J.C. \& S.F. Slater. 1990. "The Effect of A Market Orientation on Business Profitability", Journal of Marketing, page: 20-35.

Nguyen, N. \& G. LeBlanc. 2001. "Image and Reputation of Higher Education Institutions in Students' Retention Decisions", The International Journal of Educational Management, page: 303-311.

O’Connor, S.J. \& R. Shewchuk. 1995. "Service Quality Revisited: Striving for A New Orientation", Hospital and Health Services Administration, page: 535-552.

Pettigrew, A.M. 1979. "On Studying Organizational Cultures", Administrative Science Quarterly, page: $570-81$.

Pfeffer, J. \& G. Salancik. 1978. The External Control of Organizations: A Resource Dependence Perspective, New York: Harper and Row.

Reynolds, P.D. 1986. “Organizational Culture as Related to Industry, Position, and Performance: A Preliminary Report", Journal of Management Studies, page: 334-345.

Robbins, S.P. 2005. Essentials of Organizational Behavior, Eight Edition, New Jersey: PrenticeHall.

Rust, R., A.J. Zahorik \& T.L. Keiningham. 1996. Service Marketing, New York: HarperCollins/ College Publishers.

Sasser, E.W. \& T. Jones. 1995. "Why Satisfied Customers Defect", Harvard Business Review, page: 88-99.

Schein, E.H. 1968. "Organizational Socialization and The Profession of Management", Industrial Management Review, page: 1-15.

Schein, E.H. 1985. Organizational Culture and Leadership, San Francisco: Jossey-Bass Publishers.

Schlesinger, L.A. \& J. Heskett. 1991. "The ServiceDriven Service Company", Harvard Business Review, page: 71-81.
Schneider, B. \& D.E. Bowen. 1993. The Service Organization: Human Resources Management is Crucial", Organizational Dynamics, page: 39-52.

Schneider, B. \& D.E. Bowen. 1995. Winning the Service Game, Boston: A Harvard Business School Press.

Schneider, B., A.P. Brief \& R. Guzzo. 1996. "Creating a climate and culture for sustainable organizational change", Organizational Dynamics, page: 6-19.

Schneider, B., J.K. Wheeler \& J. Cox. 1992. “A Passion for Service: Using Content Analysis to Explicate Service Climate Themes", Journal of Applied Psychology, page: 705-716.

Sekaran, U. 2000. Research Methods for Business: A Skill Building Approach, Third Edition, New York: John Wiley dan Sons.

Smircich, L. 1983. "Concepts of Culture and Organizational Analysis", Administrative Science Quarterly, page: 339-58.

Tabachnick, B.G. \& L.S. Fidell. 1996. Using Multivariate Statistics, Third Edition, New York: Harper-Collins College Publisher.

Uttal, B. 1983. The corporate culture vultures. Fortune, October 17: 66-72.

Venkatraman, N. \& V. Ramanujam. 1986. "Measurement of Business Performance in Strategy Research: A Comparison of Approaches", Academy of Management Review, page: 801814.

Venkatraman, S. 2007. "A Framework for Implementing TQM in Higher Education Programs", Quality Assurance in Education, page: 92-112.

Yuniawan, A. 2009. "Pemodelan Hubungan antara Variabel Organisasional dan Variabel Pelanggan Dalam Penyampaian Layanan Serta Pengaruhnya Terhadap Retensi Pelanggan", Disertasi tidak dipublikasikan. Semarang: Universitas Diponegoro. 